\title{
JOURNAL OF PHILOSOPHICAL LOGIC
}

\author{
D. REIDEL PUBLISHING COMPANY
}

P.O. BOX $17 /$ DORDRECHT-HOLLAND

\begin{abstract}
Editor-in-Chief: Bas C. Van Fraassen, University of Toronto, Toronto, Ontario, Canada.
\end{abstract}
Contents of Volume 1, No. 2. May 1972

Ivor Grattan-Guinness / Bertrand Russell on his Paradox and the Multiplicative Axiom. An Unpublished Letter to Philip Jourdain. Dorothy L. Grover / Propositional Quantifiers. Richard E. Grandy / A Definition of Truth tor Theories with Intensional Definite Description Operators. E. L. Marsden / Compatible Elements in /mplicative Mode/s. Zane Parks / Classes and Change. N. L. Wilson / What Exact/y is English? Karel Lambert / Notes on Free Description Theory: Some Philosophical Issues and Consequences, Richard Routley and Robert K. Mever / The Semantics of Entailment III. R. H. Thomason / A Semantic Theory of Sortal Incorrectness. Kathleen Johnson Wu / Hintikka and Defensibility: Some Further Remarks. Errata.

\section{New}

Nietzsche-Studien

Internationales Jahrbuch für die Nictzsche-Forschung

Fd. by

Mazzino Montinari,

Wolfgang Müller-Lauter,

Heinz. Wenzel

Just publisbed:

Vol. 1:

Large Octavo. VIII $+470 \mathrm{pp}$.

1972. Cloth $\$ 30.00$

ISBN 3110022249
Kant-Studien

Philosophische Zcitschrift der Kant-Gesellschaft

Ed. by

Gerhard Funke and Joachim Kopper

in association with

Gottfricd Martin

63rd. year. 1972.

I arge Octavo.

Per year (4 issucs) $550 \mathrm{pp}$. $\$ 18.50$ 


\section{THEORY AND DECISION}

\section{An International Journal for Philosophy and Methodology of the Social Sciences}

Editors: G. L. Eberlein, University of Saarland, Saarbrïcken; W. Kroeber-Riel, University of Saarland, Saarbricken; W. Leinfellner, University of Nebraska, Lincoln; A. C. Michalos, University of Guelph, Guelph.

\section{CONTENTS OF VOLUME 2, No. 4}

Myles Brand / On Having the Opportunity. Edward F. McClennen / An Incompleteness Problem in Harsanyi's General Theory of Games and Certain Related Theories of NonCooperative Games. John C. Harsanyi / Notes on the so-called Incompleteness Problem and on the Proposed Alternative Concept of Rational Behavior. Helmut Laux and Hans Schnee. weiss / On the Onassis Problem.

Reviews: Hubert M. Blalock, Jr., Theory Construction from Verbal to Mathematical Formulations (Norman Stockman). Robert Dubin. Theory Building: A Practical Guide to the Con. struction and Testing of Theoretical Models (Norman Stockman). Werner Kroeber-Riel, Wissenschaftstheoretische Sprachkritik in der Betriebswirtschaftslehre (Lothar Czayka). Bela Juhos und Wolfgang Katzenberger, Wahrscheinlichkeit als Erkenntnisform (Hermann Vetter). Henry E. Kyburg. Jr., Probability and Inductive Logic (Michael Martin). B. W. Lindgren. Elements of Decision Theory (Gordon We/ty). Erich Mittenecker, Statistische Methoden in der Psychologie und den angrenzenden Wissenschaften (Ulrich Kockelhorn). K. D. Opp, Kybernetik und Soziologie (Herbert Stachowiak). Edward A. Suchman, Evaluative Research (Alex C. Michalos). Robert Paul Wolff. The Ideal of the University (Lawrence L. Haworth). Second International Game Theory Workshop, Berkeley, 1970 (Heinz J. Skala). Call for Papers. Index of Names.

Subscription price per volume of four issues US $\$ 27.20$, including postage. Five or six issues will be published yearly. Personal subscription price on request.
D. REIDEL PUBLISHING COMPANY
P.O. BOX 17
DORDRECHT_HOLLAND

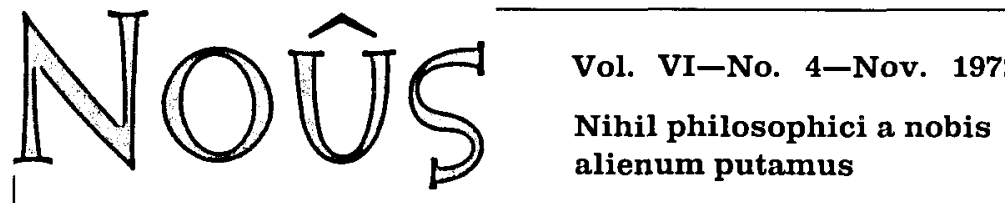

\section{CONTENTS}

Lawrence Sklar / Absolute Space and the Metaphysics of Theories

Samuel C. Wheeler / Attributives and their Modifiers

R. and V. Routley / TheSemantics of First Degree Entailment

Charles Pailthorp / On Refuting C. I. Lewis's Fallibilism Helen Morris Cartwright / Chappell on Stuff and Things Michael Jubien / The Intensionality of Ontological Commitment

\section{Recent Publications in Philosophy}

Index for Volume VI

\section{Philosophy Department, Indiana University Bloomington, Indiana 47401}


Editurial Board: William P Alston, Monroe C. Beardsley, Lewis White Beck, William A. Farle, Dagfinn Follesdal, William Frankena, Maurice Mandelbaum, R Barcan Marcus, Richard Martin, Mary Mothersill, Joseph Owens, Richard Rorty, J. B. Schneewind, Wilfrid Sellars, John E. Smith, Richard Wasserstrom.

Managing Editor, Ann FREEMAN

EACH ISSUE IS LIMITED TO ARTICLES ON A SINGLE GENERAL TOPIC

submitted papers should be receiced by the editor nine months prior to the scheduled publication date of the issue.

GENERAL TOPICS for recent and forthcoming issues:

SCHEDULED PUBLICATION DATES:

Vol. 57, No. 2 Apr., 1973 Pragmatism Reconsidered

Vol. 57, No. 3 July, 1973 Philosophic Analysis and Deep Structure

Vol. 57, No. 4 Oct., 1973 Philosophy of War

Vol. 58, No. 1 Jan., 1974 The Philosophy of Thomas Aquinas

Vol. 58, No. 2 Apr., 1974 Language of Art

Vol. 58, No. 3 July, 1974 "Sidgwick" and Moral Philosophy

Vol. 58, No. 4 Oct., 1974 The Philosophy of Moral Education

Vol. 59, No. 1 Jan., 1975 The Philosophy of Husserl

Vol. 59, No. 2 Apr., 1975 Philosophical Problems of Death

Vol. 59, No. 3 July, 1975 Language, Thought, and Reality

Vol. 59, No. 4 Oct., 1975 The Phenomenology of Mysticism

Editorial Office: Department of Philogophy, California State University

San Jose, California 95114

Business Office: Box 599, La Salle, Illinois 61301

SUBSCRIPTION RATES: United States: Annual (4 issues): Institutions, \$8, (14; individuals, $\$ 6.00$. Single copies: Institutions, $\$ 2.00$; individuals, $\$ 1.75$. Foreign postage: Add 15 cents to single copy rate or 60 cents to subscription rate.

\title{
PHILOSOPHY AND PHENOMENOLOGICAL RESEARCH
}

\section{AN INTERNATIONAL QUARTERLY}

\author{
Edited by MARVIN FARBER
}

in cooperation with a distinguished group of American and Foreign Scholars

Descriptive, analytic, critical, and historical articles representing the major contemporary trends in philosophy. In addition to papers on phenomenology, PPR published studies in a wide range of areas including ethics and value theory, metaphysics, aesthetics, logic, language, political, social, and religious philosophy, theory of knowledge, and the sciences.

\section{Address all communications to Philosophy and Phenomenological Research \\ State University of New York at Buffalo Buffalo, New York 14226}

Annual subscription rate, $\$ 9.00$ for libraries and institutions, $\$ 7.50$ for individuals; single copies $\$ 2.50$ and $\$ 2.00$ respectively, plus postage and handling on back issues only. Papers submitted for publication will not be returned unless accompanied by a self-addressed stamped envelope, or equivalent postage.

A circular listing the main contents of the Journal since 1940 will be sent upon request. 


\section{In preparation:}

\section{CONTEMPORARY RESEARCH IN THE FOUNDATION}

AND PHILOSOPHY OF QUANTUM THEORY

edited by C. A. Hooker

\section{SCIENCE, DECISION, AND VALUE}

edited by J. J. Leach, R. E. Butts, and G. Pearce

\section{CONCEPTUAL CHANGE}

edited by G. Pearce, C. A. Hooker and P. Maynard

FAITH AND THE LIFE OF REASON

by J. King-Farlow and W. N. Christensen

\section{Already published:}

\section{PHILOSOPHICAL LOGIC}

edited by J. W. Davis, D. J. Hockney, and W. K. Wilson

1969, viii + 277 pp., Dfl. 45, - ISBN 9027700753

A free subject catalogue Philosophy-Linguistics-

D. REIDEL PUBLISHING COMPANY

P.O. BOX 17 - DORDRECHT - HOLLAND

\section{the philosophy forum}

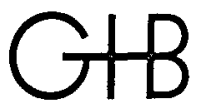

Editor: Rubin Gotesky

Executive Associate Editor: Ervin Laszlo

The Philosophy Formm publishes articles of philosophic significance on problems of direct human contact rather than on problems of a wholly technical nature. Each volume and each issue within a volume is devoted to a common topic.

The object of the Formm is to develop discussion, on a philosophic level, of issues of primary importance to mankind today; to have such issues discussed not merely by philosophers but by scientists, humanists, and others with a philosophic bent. The questions discussed are not technical insofar as they do not have a technical solution; they are questions which involve the clarification of attitudes, the illumination of problems, the search for common agreement as to what is best in the end.

For further details please zurite to:

GORDON \& BREACH SCIENCE PUBLISHERS 4 I/42 William IV Street, London WC2, England, or 440 Park Avenue South, New York, NY roor 6, USA 


\section{SYNTHESE}

An International Journal for Epistemology. Methodology and Philosophy of Science

Editor-in-Chief: Jaakko Hintikka, Academy of Finland and Stanford University Review Editor: Dagfinn Follesdal, University of Os/o Associate Editor: Risto Hilpinen, University of Turku Editorial Assistant: Juha Manninen, $\mathrm{He} / \mathrm{sinki}$

\section{Contents of Volume 23, No. 4}

Stefan Nowak / Inductive Inconsistencies and Conditional Laws of Science. Richard T. Hull / Feyerabend's Attack on Observation Sentences. Robert Howell / Seeing As. Marshall Swain / An Alternative Analysis of Knowing. Richard Rorty / Indeterminacy of Translation and of Truth. Gunnar Niemi / On the Existence of a Model Antinomy.

Discussions: Can Language Be Explained Functionally? (Geoffrey Sampson). Reply (Stephen Toulmin).

Reviews: Y. Bar-Hillel (ed.), Mathematical Logic and Foundations of Set Theory (F. R. Drake). Wolfgang Muller-Lauter, Nietzsche, Seine Philosophie der Gegensätze und die Gegensätze seiner Philosophie (Trond Berg Eriksen).

Communications of the International Union of History and Philosophy of Science Division of Logic, Methodology, and Philosophy of Science. Boston Colloquium for the Philosophy of Science (1971-1972). Books Received. Index of Names.

Subscription price per volume of four issues US $\$ 28.80$, including postage. Two volumes will be published yearly. Personal subscription price on request

\section{REIDEL PUBLISHING COMPANY}

P.O. BOX 17 DORDRECHT-HOLLAND

\section{Religious Studies}

Volume 8, Number 3, September 1972

\section{Contents}

R. G. SWINBURNE The Argument from Design-a Defence J. BRENTON STEARNS The Naturalistic Fallacy and the Question of the Existence of God

H. P. OWEN The New Testament and the Incarnation: A study in Doctrinal Development

THOMAS F. TORRANCE Newton, Einstein and Scientific Theology

TAN TAI WEI Professor Langford's Meaning of 'Miracle'

Review Articles

ERROL E. HARRIS Reasonable Belief

A. D. GALLOWAY The New Hegelians

\section{Reviews}

11.30net (\$4.00 in the USA). Annual subscription

$\$ 4.00$ net ( $\$ 13.50$ in the USA).

\section{CAMBRIDGE UNIVERSITY PRESS}

Bentley House, 200 Euston Road, London NW1 2DB

American Branch: 32 East 57th Street, New York, N.Y. 10022 


\title{
An International Quarterly Index
}

\section{To Philosophical Periodicals}

The Philosopher's Index is an up-to-date quarterly index of articles from more than one hundred and fifty major philosophy journals and related interdisciplinary publications. Articles are indexed by subject and author. Abstracts of the articles are published in each issue and are written by the authors of the articles. In addition, the Index contains a Book Review Index.

The Quarterly, Paperback, $\$ 20$ (Individuals: \$10)

Annual Cumulative Edition, Hardbound, \$25 (Individuals: \$15)

U.S. and Canada:

\author{
THE PHILOSOPIIER'S INDEX \\ BOWLING GREEN UNIVERSITY \\ BOWLING GREEN, OHIO 43403 USA
}

Outside the U.S. and Canada:

D. REIDEL PUBLISHING COMPANY/DORDRECHT, HOLLAND

\section{FOUNDATIONS OF LANGUAGE}

\section{International Journal of Language and Philosophy}

Board of Editors: Morris Halle, M.I.T.; Peter Hartmann, Konstanz; K. Kunjunni Raja, Madras; Benson Mates, Univ. of California; J. F. Staal, Univ. of California; Pieter A. Verburg. Groningen; John W. M. Verhaar, Djakarta.

Editorial Assistants: W. G. Klooster and H. J. Verkuyl.

Contents of Volume B, No. 4

Matthew Chen / The Time Dimension: Contribution Ioward a Theory of Sound Change. Teun A. van Dijk, Jens Ihwe, Janos S. Petöfi, and Hannes Rieser / Two Text Grammatical Models. A Contribution to Formal Linguistics and the Theory of Narrative. Joseph Emonds / Evidence that Indirect Object Movement is a Structure-Preserving Rule. James Peter Thorne / On the Notion ' $D$-finite: George Lakoff / Performative Antinomies. John Robert Ross / Parentage. John Robert Ross / More on begin.

Roviews: Dhirendra Sharma / The Differentation Theory of Meaning in Indian Logic (Bimal Krishna Matilal). Ósten Dahl / Topic and Comment: A Study in Russian and General Transformational Grammar (Wayles Browne). Wolfgang Schlachter / Arbeiten zur strukturbezogenen Grammatik auf der Grundlage finnisch-ugrischen und indogermanischen Materials (Werner Abraham). Hpo Tapani Piirainen / Graphematische Umtersuchungen zum Frühneuhochdeutschen (Werner Abraham) Karl-Ludwig Harth / Gesprochenes Deutsch. Ein Arbeitsbuch äber Wesen. Erscheinung und Technik gesprochener Information (Stank Zepiç). H. G. Hubbeling / Inleiding tot het denken van Wittgenstein (W. A. de Pater).

Announcement. Index of Names.

Subscription price per volume of four issues DfI. 115 (US \$37.38), including postage.

About six or seven issues are published yearly. Personal subscription price on request.
D. REIDEL PUBLISHING COMPANY
P.O. BOX 17 - DORDRECHT-HOLLAND 


\title{
ZEITSCHRIFT FUR ALLGEMEINE WISSENSCHAFTSTHEORIE
}

\author{
Journal for General Philosophy of Science \\ Edited by Alwin Diemer . Lutz Geldsetzer . Gert Konig \\ Per year 2 issues of 106 pp. each Annual subscription DM 56,-
}

From the contents of vol. 2

ULRICH ALBRECHT, Die Werturteilsfrage in der Technik

KARL-OTTO APEL, Wissenschaft als Emanzipation? Eine Auseinandersetzung mit der

Wissenschaftskonzeption der "Kritschen Theorie"

MARIO BUNGE, The Physicist and Philosophy

ALWIN DIEMER, Zur Grundlegung eines allgemeinen Wissenschaftsbegriffes

MICHAEL MARTIN, An Explicative Model of Theory Testing

HUBERT SCHLEICHERT, Uber die logische Stellung der relativistischen Me theorie

WOLFGANG STEGMULLER, Wissenschaft und Erklarung

BERICHTE

JOHS. WITT-HANSEN, Philosophy of Science (Wissenschaftstheorie) in Denmark

GERHARD ZECHA, Die gegenwartige Situation der Wissenschaftstheorie in Osterreich

FRANZ STEINER VERLAG GMBH WIESBADEN, GERMANY

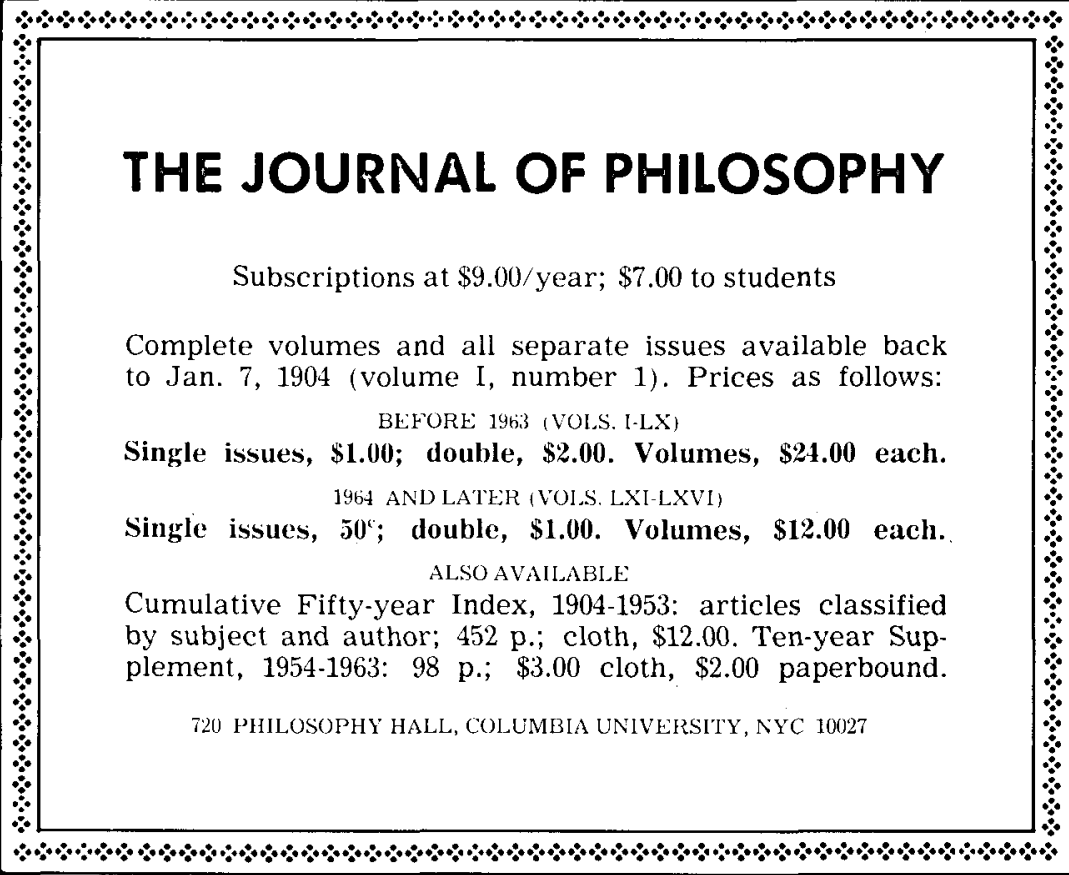




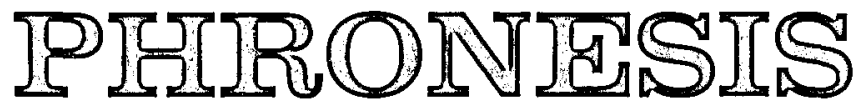

\section{A journal for ancient philosophy}

PHRONESIS appears three times a year and provides articles and studies in English, French, German and Latin by experts of international standing. Each issue contains 96 pages.

Managing editor: Prof. David J. Furley Dept. of Classics

Princeton University. PRINCETON, N. J. USA

Subscription: Per annum Hfl. 37,00 (\$12.00)

Back-volumes are available

Publishers: ROYAL VANGORCUM LTD.

ASSEN, The Netherlands

\section{PHILOSOPHICAL STUDIES}

\section{An International Journal for Philosophy in the Analytic} Tradition

Editor: Wilfrid Sellars, University of Pittsburgh, U.S.A.

Board of Consulting Editors: David Braybrooke, Dalhousie University. Canada: May Brodbeck, University of Minnesota, U.S.A. L. J. Cohen, Queens College, England, James Cornman, University of Pennsy/vania, U.S.A.; Alan Donagan, University of Chicago, U.S.A.; Herbert Feigl, University of Minnesota. U.S.A.: Rudolf Haller, The University of Graz, Austria: Mary Hesse, University of Cambridge, England: Risto Hilpinen, University of Turku. Finland; John Hospers, University of Southern California, U.S.A.: Keith Lehrer, University of Rochester, U.S.A.; R. M. Martin, New York University, U.S.A.: Gunther Patzig. The University of Göttingen. West Germany; A. M. Quinton, New College. Oxford, England; Judith Thomson, Massachussetts institute of Technology, U.S.A.

\section{Contents of Volume 23, No. 5}

October 1972

Richard Schacht / Husserlian and Heideggerian Phenomenology. Raziel Abelson / Rejoinders. Michael Martin and Henry Ruf / Silverstein's Defense of Cornman. Harry S. Silverstein , Reply to Martin and Rut. Bruce Aune / Remarks on Argument by Chisholm. David Coder / Strawson. Particulars. 'No-Subject' and 'no-Ownership' Robert H. Vorsteg / Are Explication Statements Empirical? Peter van Inwagen / Lehrer on Determinism, Free Will, and Evidence. John Turk Saunders / Thalberg's Challenge to Justification via Deduction.

Subscription price per volume of six issues US $\$ 30.40$, including postage. One volume is published yearly.

Personal subscription price on request.

D. REIDEL PUBLISHING COMPANY

P.O. BOX 17-DORDRECHT-HOLLAND 